\title{
POLISH MODEL OF ADMINISTRATIVE PROCEDURE
}

\section{Elena Markova}

Candidate of Law Science, Associate Professor, Associate Professor at the Department of Legal Disciplines, Sumy Branch of Kharkov National University of International Affairs, Ukraine e-mail: helena.sherstuk@gmail.com,orcid.org/0000-0001-9970-0944

\section{Summary}

In the article, the author examines the Polish model of administrative procedure, its nature, structure, taking as a basis the work of Javier Barnes in which the scientist identifies three generations of administrative procedure with the elements: (1) procedure for adjudication, (2) rule-making procedure, (3) collaborative - making public policy and implementing procedure.) The model of administrative procedure in Poland is normative as it is enshrined in the Code of Administrative Procedure. After analyzing its provisions, the author came to the conclusion that the Polish model of administrative procedure has a pronounced jurisdictional character, which is indicated by the principles of administrative proceedings, the structure of administrative proceedings. The jurisdictional model of administrative procedure in Poland remains dominant; it is characterized by a clear polarization of roles, with a "powerful sovereign" on the one hand and a subordinate citizen on the other.

However, the Code reflects the provisions that indicate the partial appearance in the classical model of the administrative procedure of the elements of the third generation, which is associated with convergence and globalization. Poland's membership in the European Union prompted the legislator to introduce new, additional provisions in the Code of Administrative Procedure, concerning, for example, Administrative European Cooperation Section 8a, the principle of the peaceful settlement of Art. 13, the use of mediation in administrative proceedings Art. 96a. The presence of these elements is aimed at overcoming this division, creating a relationship between the parties, according to the principle of horizontal communication. The nature of the jurisdictional model of the administrative procedure is changing towards the regulation of a wide range of activities of bodies in the public sphere. Establishing a permanent system of communication between bodies, and between bodies and citizens "becomes the goal of the administrative procedure. Such changes are in line with the requirements of European Union legislation and the principles enshrined in the Code of Administrative Procedure.

Keywords: generation of administrative procedure, jurisdiction model.

\section{DOI: https://doi.org/10.23856/4917}

\section{Introduction}

Various factors of historical, legislative and managerial nature have influenced the emergence and content of the model of legal procedure in general and administrative procedure in particular. In each country must operate not only an effective mechanism of making administrative judicial decisions, but also a mechanism of making administrative decisions (administrative rulemaking) (system of administrative rulemaking). As a result of their functioning a large number of types of administrative procedures have emerged and certain models aimed at performing new tasks and functions in accordance with the new conditions of collaborative governance and directions of administrative reform. 
The existence of different models of administrative procedure in European countries is due to the different legal traditions of European countries as well as to the dynamic changes taking place in modern administrative systems. This means that so far it has not been possible to create a single European model of administrative procedure containing detailed regulation of all issues. There is a provision in European Union law that each Member State retains its procedural autonomy, but this provision is conditional, as autonomy is only present if there is no relevant EU regulation that excludes procedural autonomy of Member States in a particular matter or area. EU Directives often set out complex remedies and impose an obligation on European countries to take decisions in administrative procedure, which often differ from those taken under and on the basis of national law.

The doctrine notes that increasing trends of harmonization and unification led to indirect decodification of the provisions of the Polish Code of Administrative Procedure, to the reduction of procedural autonomy of Poland (Kmieciak, 2010:92). In recent years at the level of European supranational organizations measures have been taken to standardize, harmonize - and so far unsuccessfully - unify the rules of administrative procedures.

It should be noted that the Council of Europe has adopted many soft law acts in the field of administrative procedure 361 that enshrine basic general principles of administrative procedure: Council of Europe Committee of Ministers Recommendation CM / Rec (2007) 7 on the right to good governance (Recommendation CM/Rec(2007)); Charter of Fundamental Rights of 07.03. 2000 (Charter of Fundamental Rights of the European Union), European Code of Good Administrative Conduct 2001 (The European Code of Good Administrative Behavior, 2001), Lisbon Treaty (Treaty of Lisbon, 2007), which created the basis for cooperation between the EU member states, whose provisions were reflected in the Code of Administrative Procedure under "Administrative cooperation" (Kodeks postępowania administracyjnego, 1960). Further European codification activities were aimed at unifying the legal solutions in the field of administrative proceedings of the EU Member States. In 2013 the European Parliament obliged the European Commission to present a draft of a single European administrative procedure code, which would be binding for the bodies of the European Union.

We can draw an intermediate conclusion that the general legislative policy of the European Union in the field of administrative procedure has influenced the legislation of EU countries, including Poland, by changing the nature of administrative procedure model and its content, forming "dependence" in order to reduce national procedural autonomy.

The aim of our article is to analyze the provisions of the Polish Code of Administrative Procedure for the content of the elements of administrative procedure of the first, second and third generation.

\section{Main part}

For the first time models of administrative procedure of the first, second and third generation were developed and proposed by Javier Barnes [Barnes, 2009:41]. The scientist distinguished three generations of administrative procedure taking as a basis the management model: (1) adjudication procedure, (2) rule-making procedure, (3) collaborative-making public policy and implementing procedure). Based on the views of Xavier Barson, Polish scientist Zbigniew Kmieciak distinguished three models of administrative procedure: judicial, legislative and administrative (Kmiecik, 2011:53).

The scholar called the judicial model a "courtroom" procedure and drew attention to the need for a "complete renewal and transformation" of this model. European administrative scientists emphasized the need for "reorientation" of national concepts of administrative 
procedure. It should be shared the scholar's observation that any "genetic" relationship between administrative proceedings and the model of judicial proceedings has as its common source - the concept of protection of public subjective rights. The scientist stressed that administrative proceedings traditionally focused on the resolution of individual administrative cases between public administration bodies and individuals (legal entities). Considering administrative proceedings only from the jurisdictional point of view, scientists come to the view about its unreliability in cases where there is a need to protect disparate group interests in conflict situations, in which an administrative body acts not only as a subject resolving an administrative case, but also as a mediator - conciliator. The classical means of litigation prove to be unreliable in such cases and need to be supplemented by more modern solutions. For example, in administrative proceedings in which one of the parties is a group of persons it is necessary to use mediation in order to work out and reach a mutually acceptable solution in the form of an agreement (ugoda). Some changes to the Code of Administrative Procedure have been influenced by European legislation in order to eliminate shortcomings related to the lack of elements of the third generation model of administrative procedure.

General administrative proceedings are called jurisdictional due to their connection and similarity to judicial proceedings and refer it to the first generation of administrative procedure. The analogy can be traced not only in the structure (stages), but also in the principles on which the administrative procedure is based. Attempts of scientists to comprehensively consider issues related to the formation of jurisdictional model of administrative proceedings are presented through general principles, which are enshrined in the Code of administrative procedure. Therefore, it is in the principles reflected jurisdictional (judicial) nature of the model of administrative procedure.

We need to pay attention to the main determinants that define the model of administrative procedure as jurisdictional, namely: 1) the principles of administrative proceedings; 2) the structure of proceedings; 3 ) the form of objectification of the results of the procedure, 4) the model of appellate administrative proceedings (review). And consider them through the prism of comparison with the judicial procedure in order to speak about the presence of a certain analogy with the judicial procedure.

General principles of administrative procedure are the norms guiding the procedure, recognized as such by the legislator and highlighted in Chapter 2, Articles 6-16 of the Code of Administrative Procedure. Among the general principles there are principles that define the model of this procedure as jurisdictional: (for example, principles: formality, objective truth, principle of written form of procedure, two instances), as well as a number of others that determine the actions of bodies in these proceedings. For example, the principle of two instances is a constitutional principle enshrined in Article 78 of the Constitution of the Republic of Poland, which states: "Each party shall have the right to appeal against the judicial decisions and decisions of the authorities rendered in the first instance. Exceptions to this principle and the procedure for appealing against it shall be determined by law". The jurisprudence of the Constitutional Court emphasizes that the purpose of the principle is to guarantee the person the right to appeal against court decisions and decisions of bodies to a higher authority to verify (control) the correctness of the decision.

In administrative proceedings, this principle is enshrined in Article 15 of the AOC (administrative proceedings may be conducted in two instances, unless otherwise stipulated by a special provision of Article 15 and Article 127. A party may appeal a decision rendered in the first instance. A higher-level public authority shall be competent to hear the appeal, unless another appeal body is provided for by law. A decision rendered in first instance by a minister or a local government appeals board may not be appealed, but if a party is not satisfied with the decision, it may apply to that body for a review of the case.

We can see that the principles of administrative procedure are based on the principles of judicial procedure, but there are also principles based on the EU soft law acts in the field 
of administrative procedure, which we mentioned above. They are the principles of the third generation model of administrative procedure, namely Articles 9, 10, 7b, 13: principle of informing the parties, active participation of the parties in the proceedings, peaceful settlement of cases, cooperation of public administration. These principles complement the classical ones, giving administrative proceedings a democratic and modern character.

An analogy with court proceedings can also be traced in the structure of administrative procedure, namely in the stages: 1) preliminary stage (consists of procedural actions of bodies to initiate administrative proceedings, as well as to check the admissibility of the initiation procedure; 2) investigation stage (includes a number of procedural actions aimed at establishing the circumstances of the case, which entailed the application of substantive law and consideration of an administrative case); 3) decision-making (holding a hearing and decision on an individual case of a particular person, i.e. the case that is the subject of proceedings in the form of a decision or consult 4) appealing the decision; 5) execution of the decision.

Regarding the form of objectification of the results of proceedings we note that consideration by a public administration body of an individual case is carried out by adopting an administrative decision, unless otherwise provided for by the provisions of the Code (article 104 part 1 of the AOC). Administrative decision can be defined as a unilateral, imperative expression of will of a public administration body, addressed to a specific external addressee, and taken in the manner and form provided for by the Code. Administrative decision is one of the most common and basic forms of objectification of the results of proceedings, which is used by a public administration body to resolve individual issues concerning citizens (Itrich-Drabare, 2018: 45). It allows resolving individual cases without initiating court proceedings (Kmieciak, 2009: 228). The provisions of the Code of Administrative Proceedings also provide for the possibility to settle administrative proceedings that have not yet been completed by means of ugody administracyjnej, if the nature of the case allows and this possibility is not excluded by specific provisions. The administrative contract is the second form in which the outcome of administrative proceedings can be objectified. The provisions of Articles 117-121 of the CAP apply to the agreement concluded through mediation.

Having analyzed the model of general administrative proceedings from the jurisdictional side, having considered specific doctrinal and legislative arguments, let us proceed to consider the elements of the third generation model of administrative procedure.

Jurisdictional model of administrative proceedings remains the dominant model, it is characterized by a clear polarization of roles, with the "power sovereign" on the one hand and the subordinate citizen on the other. Procedure of the third generation is a diametrically opposite model, which aims at overcoming this division, creating relations between the parties on the principle of horizontal communication (Barnes, 2009:32).

Display of provisions in the CAP which show the partial emergence of third generation elements in the classical model of administrative procedure, which is connected with convergence and globalization. First and foremost, it is Poland's membership in the European Union which prompted the legislator to introduce new, additional provisions into the Code of Administrative Procedure, such as Section 8a administrative European cooperation, the principle of peaceful settlement of cases Article 13, the use of mediation in administrative proceedings Article 96a. Poland's accession to the European Union has fundamentally changed the model of law application by both public administration authorities and courts. The emergence of new sources of law in the legal system - due to accession - has created new problems, including the need to harmonize two different legal regimes, or rather the need to combine them in such a way as to ensure that the objectives of national law and Community law are met. As noted in the literature, Poland's membership of the European Union has had a strong impact on administrative law, since its formation is no longer the sole task of the national legislator. In the Polish literature, much attention is paid to the impact of Community law on the judicial activities of courts, Polish bodies, which highlights the many doubts and controversies that arise in this regard. 
With regard to administrative proceedings it was necessary to provide for and ensure the optimal implementation of EU laws in the general regulation of administrative procedure in the national legislation. Provisions of the Code regulate issues related to cooperation and interaction not only between citizens, organizations and public administration authorities, but also between different public administration authorities, both at the state and at the interstate level. The nature of administrative procedure is changing towards regulating a wide range of activities of bodies in the public sphere. "Establishing a permanent system of communication between bodies, and between bodies and citizens" becomes the goal of public administration. Such changes are in line with the requirements of the European Union legislation and the principles enshrined in the Code of Administrative Procedure.

In the traditional Polish concept of administrative proceedings, the third generation elements are still a kind of terra incognita for it. In Polish system of administrative law the third generation elements are included in the Act of 3 October 2008 on the provision of information on the environment and its protection, public participation in environmental protection and environmental impact assessment. Within its scope this act implements the directives of European Communities, in particular the Directive 2001/42/EC of 27 June 2001 on the assessment of the effects of certain plans and programs on the environment, hereinafter called "the environmental directive". It stipulates and enshrines the possibility of expression of opinion, consultation (expression of opinion, consultation (Article 6) as well as cross-border consultation with EU member states (Article 7), informing about the decision and monitoring.

Let us consider the provisions of the Code on Administrative Proceedings for the content and fixation of the elements of the model of administrative procedure relating to the third generation. In the opinion of Polish scholars, the content of the principles enshrined in Articles 9 and 10 of the AOC show that they contain features characteristic of the third generation of administrative procedure. Article 9 stipulates that public administration authorities are obliged to inform the parties properly about the factual and legal circumstances of the case, which may affect their rights and obligations that are the subject of administrative proceedings. The right of access to such documents may be limited by provisions on the protection of personal data and classified information. The principle of transparency in the activities of public authorities (Article 10) is revealed in Article 10 through the obligation of authorities to ensure active participation of the parties at all stages of the proceedings.

The reason why most of the amendments introduced over the years to the 1960 CAP were based on an attempt to implement the postulate of simplifying the procedure and increasing its efficiency by adopting administrative acts that would meet the requirements set out in the basic rules of procedure and at the same time increase their level of acceptability for the addressees. One of the mechanisms to implement this postulate is to create a framework for the real participation of the citizen in the process of exercising his rights and obligations. The form of its implementation may include, mediation, which is usually a type of negotiation between the parties to the conflict involving an impartial and independent third party, called a mediator. The basis for the practical application of mediation in administrative proceedings is the principle of amicable settlement of the case enshrined in Article 13. Public administration authorities shall seek an amicable settlement of the case in question, if the nature of the case allows, by taking actions to induce the parties to conclude an agreement in the framework of mediation.

Since 1 June 2017, mediation became part of the Polish model of jurisdictional administrative proceedings. As a manifestation of the introduction of alternative dispute resolution (ADR) methods in public law, it aims at reaching a solution that is acceptable to both parties. The enshrining of provisions on the possibility to use mediation in administrative proceedings is a consequence of the "Europeanisation of administrative law", understood as the process of influencing national legal systems, including administrative law, by EU legislation or soft law adopted by the Council of Europe. Mediation is the result of "borrowing" from foreign legal systems in line with the trend towards voluntary harmonization with regard to the drafting and adoption of procedural decisions in 
European countries. The mediation enshrined in the AOC fulfils different functions: on the one hand, it allows to reach mutual agreements under the guidance of a mediator, the achievement of which makes an administrative decision unnecessary. On the other hand, it improves communication and clarifies legal or factual differences identified in the proceedings.

A modern administration has not only to decide on the rights and duties of a person (which sometimes leads to a conflict with the latter), but also to reconcile subjects with conflicting interests. Various forms of proceedings are known in Polish law whereby an administrative body is appointed to carry out mediation tasks. The procedural basis for the actions of the administrative body to apply mediation in individual cases involving parties with disputed interests is the provisions of the Code of Administrative Proceedings (articles 13 and 114-122). According to Article 13 of the Code of Administrative Proceedings, these issues may be resolved in the form of an agreement drawn up before a public administration body. In such cases, the administrative agency in charge of the case shall "take actions aimed at inducing the party to settle the case by means of an agreement". This provision implies an obligation on the administrative body to initiate actions to reach an agreement between the parties. This is certainly some form of ex officio mediation, since the actions to persuade the parties to conclude an amicable agreement are included in the settlement of the case pending before the administrative authority and are the result of its competence. Having analyzed the provision concerning mediation and the principle of amicable settlement of the case, we believe that the Polish legislator has taken into account the EU requirements and recommendations regarding the use of mediation in administrative cases.

A further provision that demonstrates the existence of elements of a third generation model of administrative procedure is Section 8 of the CAP on administrative European cooperation. The principle of cooperation, mutual respect and assistance in achieving the EU objectives is enshrined in Article 4 (3) of the Treaty on European Union. The need for cooperation in administrative procedures in various areas, as stated in the provisions of secondary EU legislation, prompted Poland to include cross-border cooperation mechanisms in the Code of Administrative Procedures. Chapter VIIIa of the CAP on European administrative cooperation (Articles 260a to 260g), introduced by the Amending Act of 7 April 2017 is intended to provide and establish an orderly set of rules intended for cooperation between national administrative authorities and administrative authorities of other EU Member States as well as with EU institutions. European administrative cooperation is to be implemented in cases specified in the provisions of EU law. In this context, the provision introduced is of an auxiliary nature, as such assistance shall be provided where provided for under EU law and on the basis of EU regulations. The competence to grant administrative assistance is determined in accordance with the Code of Administrative Procedure, unless otherwise provided for by the EU law. The application of the provisions of the Polish CAP will be excluded if there is a conflict with the provisions of EU law that regulates cooperation in the given administrative area.

\section{Conclusion}

Thus, Poland, like the rest of the national legal systems, is currently undergoing radical changes towards the development of a new third generation model of administrative procedure. The changes taking place in Polish administrative procedure ensure an effective implementation of EU law in the national legislation. After Poland became a member of the EU, the model of administrative procedure was supplemented with borrowed elements in the form of European institutions: European administrative cooperation, mediation.

Elements of the second generation - provisions on rulemaking are absent in the Polish model of administrative procedure. The Polish model of administrative procedure has more of a pronounced jurisdictional character, which is indicated by the principles of administrative proceedings, the structure of administrative proceedings. The general structure of administrative proceedings resembles that of court proceedings, consisting of similar stages and phases. 
The basic principles on which administrative proceedings are based are traditionally the result of the activities of courts in their jurisprudence, however, we cannot but point out the presence of principles that are European in origin.

Given the doctrinal and legislative review presented above, it should be recognized that administrative procedure is now no longer only a jurisdictional model, it has gradually started to incorporate elements of the third generation model, such as: the use of mediation, the use of proceedings to resolve issues related to cooperation with the EU. The convergence of models of administrative procedure takes place through principles which are fundamental guidelines in the direction of the development and implementation of the "new model".

\section{References}

1. Kmieciak, Z. (2010). Postepowanie administracyjne $i$ sądowoadministracyjne a prawo europejskie, Warszawa, P. 92-93.

2. Recommendation CM/Rec(2007)7 of the Committee of Ministers to member states on good administration: (Adopted by the Committee of Ministers on 20 June 2007 at the 999 bis meeting of the Ministers' Deputies. URL: https://rm.coe.int/cmrec-2007-7-of-the-cm-to-ms-on-good

3. Charter of Fundamental Rights of the European Union: November 7, 2000. URL: https://zakon. rada. gov. ua/laws/show/994_524\#Text

4. The European Code of Good Administrative Behavior (6 September 2001). URL: https://www.cvce.eu/content/publication/2003/3/10/1b633730-1555-4b88-ac05-b868ae5cc6ac 5. Treaty of Lisbon amending the Treaty on European Union and the Treaty establishing the European Community, 2007. URL: https:/leur-lex.europa.eu/legal-content/EN/TXT/?uri= celex\%3A12007L\%2FTXT

6. Kodeks postępowania administracyjnego : Ustawa $z$ dnia 14 czerwca $1960 \quad$ r. ISAP - Internetowy System Aktów Prawnych. URL: https://isap.sejm.gov.pl/isap.nsf/DocDetails.xsp?id=WDU19600300168

7. Barnes, J. (2009). Transforming Administrative Procedure. Towards the third generation of administrative procedures: Paper of Workshop on Comparative Administrative Law, Yale Law School. P. 1-28.

8. Kmiecik Z. R. (2011). Postępowanie administracyjne, postępowanie egzekucyjne $w$ administracji i postepowanie sadowoadministracyjne. Warszawa. P. 53, 61.

9. J. Itrich-Drabare (2018). Encyklopedia administracji publicznej, Elipsa, Warszawa, P. 45.

10. Kmieciak Z. (2009). Postepowanie administracyjne $i$ sadowoadministracyjne a praw europejskie. Warszawa. P. 228.

11. J. Barnes, Transforming administrative procedures, Yale, 2009. P. 32 